\title{
EGFR Antisense DNA BB-401
}

National Cancer Institute

\section{Source}

National Cancer Institute. EGFR Antisense DNA BB-401. NCI Thesaurus. Code C156732.

A recombinant, plasmid DNA expression vector encoding a 39 nucleotide (nt) short hairpin RNA (shRNA) specific for the epidermal growth factor receptor (EGFR), with potential antineoplastic activity. Upon intratumoral administration, the EGFR antisense DNA BB-401 is taken up by tumor cells and shRNA is transcribed. The shRNA is converted into small interfering RNA (siRNA) via the RNA interference (RNAi) pathway. The siRNA targets and binds to EGFR RNA expressed by tumor cells. This blocks EGFR mRNA translation and prevents EGFR protein expression. 